\title{
OPTIMALISASI PENERAPAN MODEL PEMBELAJARAN READING ALOUD WITH COMPREHENSION (RAC) UNTUK MENINGKATKAN KEMAMPUAN MEMBACA PERMULAAN SISWA SEKOLAH DASAR
}

\author{
Ernalis, D. Syahruddin, Yunus Abidin ${ }^{1}$
}

\begin{abstract}
ABSTRAK
Masalah penelitian ini dibatasi pada masalah utama yang muncul dalam pembelajaran membaca permulaan di sekolah dasar. Masalah tersebut adalah kurang terbinanya keterampilan membaca permulaan para siswa. Faktor utama yang menyebabkan hal tersebut adalah belum diterapkannya model pembelajaran membaca permulaan yang tepat bagi siswa. Sejalan dengan masalah ini tujuan penelitian yang hendak dicapai melalui penelitian ini adalah untuk mengetahui, menjelaskan, dan memaparkan (1) perbedaan kemampuan membaca permulaan antara siswa SD yang mendapatkan pembelajaran dengan menggunakan model RAC dan yang tidak menggunakan model RAC dan (2) faktor-faktor utama yang mendukung kemampuan membaca pemahaman siswa sekolah dasar. Penelitian ini dilaksanakan dengan menggunakan metode penelitian campuran tipe eksplanatori. Subjek penelitian ini adalah guru dan siswa sekolah dasar di Kecamatan Cileunyi Kabupaten Bandung dan Kecamatan Ujungberung Kota Bandung. Data Penelitian akan dikumpulkan dengan menggunakan instrumen (1) kuesioner (2) wawancara, (3) penilaian hasil belajar, (4) penilaian proses/keterampilan, (5) catatan lapangan, dan (6) dokumentasi. Data hasil penelitian akan diolah dengan menggunakan teknik pengolahan data kualitatif dan teknik pengolahan data kuantitatif dengan uji statistika. Berdasarkan hasil pengolahan data diketahui bahwa (1) terdapat perbedaan kemampuan membaca permulaan antara siswa SD yang mendapatkan pembelajaran dengan menggunakan model RAC dan yang tidak menggunakan model RAC dan (2) faktor-faktor utama yang mendukung kemampuan membaca pemahaman siswa sekolah dasar adalah faktor intensitas membaca, strategi pembelajaran membaca, dan pengayaan bahan bacaan.
\end{abstract}

Kata Kunci: kemampuan membaca, model pembelajaran RAC, siswa sekolah dasar

\section{A. PENDAHULUAN}

Membaca merupakan salah satu keterampilan berbahasa yang diajarkan dalam mata pelajaran bahasa Indonesia di sekolah dasar. Keterampilan membaca sebagai salah satu keterampilan berbahasa tulis yang bersifat reseptif perlu dimiliki siswa SD agar mampu berkomunikasi secara tertulis. Oleh karena itu, peranan pengajaran Bahasa Indonesia khususnya pengajaran membaca di SD menjadi sangat penting. Peran tersebut semakin penting bila dikaitkan dengan

\footnotetext{
${ }^{1}$ Dosen UPI Kampus Cibiru
} 
tuntutan pemilikan kemahirwacanaan dalam abad informasi. Akhirnya, pengajaran Bahasa Indonesia di SD perlu diarahkan pada tercapainya kemahirwacanaan.

Keterampilan membaca dan menulis, khususnya keterampilan membaca harus segera dikuasai oleh para siswa di SD karena keterampilan ini secara langsung berkaitan dengan seluruh proses belajar siswa di SD. Keberhasilan belajar siswa dalam mengikuti proses kegiatan belajar mengajar di sekolah sangat ditentukan oleh penguasaan kemampuan membaca mereka. Siswa yang tidak mampu membaca dengan baik akan mengalami kesulitan dalam mengikuti kegiatan pembelajaran untuk semua mata pelajaran. Siswa akan mengalami kesulitan dalam menangkap dan memahami informasi yang disajikan dalam berbagai buku pelajaran, buku-buku bahan penunjang dan sumber-sumber belajar tertulis yang lain. Akibatnya, kemajuan belajarnya juga lamban jika dibandingkan dengan teman-temannya yang tidak mengalami kesulitan dalam membaca. Sejalan dengan kenyataan di atas, Sánchez (2013) menyatakan bahwa

"Reading as a core subject, has played a key role in our educational system as we know it since the 20th century. Nowadays the philosophy of teaching reading is more structured. conductivist point of view. This is why reading is a complex interactive process which involves on the part of the reader not only perception and identification of letters but also interaction of thought and language."

Pembelajaran membaca di SD dilaksanakan sesuai dengan pembedaan atas kelas-kelas awal dan kelas-kelas tinggi. Pelajaran membaca dan menulis di kelaskelas awal disebut pelajaran membaca dan menulis permulaan, sedangkan di kelas-kelas tinggi disebut pelajaran membaca dan menulis lanjut. Tujuan membaca permulaan di kelas I adalah agar siswa dapat membaca kata-kata dan kalimat sederhana dengan lancar dan tepat.

Kelancaran dan ketepatan anak membaca pada tahap belajar membaca permulaan dipengaruhi oleh keaktifan dan kreativitas guru yang mengajar di kelas I. Dengan kata lain, guru memegang peranan yang strategis dalam meningkatkan keterampilan membaca siswa. Peranan strategis tersebut menyangkut peran guru sebagai fasilitator, motivator, sumber belajar, dan organisator dalam proses pembelajaran. Guru yang berkompetensi tinggi akan sanggup menyelenggarakan tugas untuk mencerdaskan bangsa, mengembangkan pribadi manusia Indonesia seutuhnya dan membentuk ilmuwan dan tenaga ahli. Lebih lanjut, Hamra dan Syatriana (2012) menyatakan bahwa "Many research results indicate that the lecturers' role is an essential part in forming students to be good readers. The studies indicate that the teacher is a more important variable in reading instruction than are the teaching methods and instructional materials." 
Bertemali dengan proses pembelajaran membaca permulaan tersebut, masalah yang timbul saat ini bukanlah terletak pada ketidakmampuan siswa membaca permulaan. Yang terjadi saat ini adalah justru bahwa siswa yang masuk sekolah dasar telah memiliki kemampuan membaca dan menulis permulaan. Hal ini sejalan dengan kenyataan bahwa para siswa baru sekolah dasar tersebut telah menempuh pendidikan anak usia dini baik melalui taman kanak-kanak maupun kelompok bermain. Pendidikan anak usia dini memang seyogyanya tidaklah mengajarkan membaca dan menulis, namun dalam kenyataannya satuan PAUD tersebut telah mengajarkan membaca menulis secara dini kepada siswa sehingga siswa telah mampu membaca dan menulis ketika masuk sekolah dasar.

Siswa baru sekolah dasar yang telah memiliki kemampuan membaca dan menulis permulaan tersebut memang secara teknis memudahkan guru sekolah dasar karena tidaklah harus mengajarkan kembali membaca dan menulis permulaan. Di sisi lain, kondisi ini melahirkan masalah baru yakni hilangnya peran guru dalam pembelajaran bahasa Indonesia khususnya dalam pembelajaran membaca dan menulis permulaan. Hal ini berdampak pada monotonnya pembelajaran membaca dan menulis permulaan di sekolah dasar karena siswa dianggap telah memiliki standar kompetensi yang diharapkan. Kondisi ini melahirkan sejumlah masalah yang antara lain siswa dipaksa melakukan kegiatan membaca dan menulis yang sebenarnya harus dilakukan pada saat mereka naik ke kelas dua ataupun yang lebih banyak terjadi para siswa tetap diberikan pembelajaran membaca permulaan yang sama sebagaimana mereka telah pelajari ketika menempuh PAUD sehingga mereka menjadi bosan belajar bahasa Indonesia.

Kedua kondisi yang terjadi tersebut melahirkan sejumlah masalah baru yang harus dipecahkan. Masalah pertama adalah bahwa siswa memiliki sikap negatif terhadap pembelajaran bahasa Indonesia yang dianggap monoton dan kurang menantang. Sikap ini terbukti dengan kenyataan bahwa siswa kebanyakan lebih senang belajar mata pelajaran lain yang dianggap lebih menantang dan lebih jauh mereka menganggap pembelajaran bahasa Indonesia tidaklah penting. Masalah kedua adalah bahwa keterampilan membaca permulaan para siswa tidaklah berkembang lebih baik karena pembelajaran yang berlangsung masih sama dengan pembelajaran yang telah siswa tempuh sebelumnya. Hal ini sejalan dengan kenyataan bahwa hampir tidak temui upaya guru dalam mengkreasi pembelajaran agar siswa memiliki keterampilan membaca yang lebih baik. Masalah ketiga adalah lemahnya orientasi perolehan pengetahuan bagi para siswa selama pembelajaran membaca yang seharusnya pembelajaran ini lebih dipadukan dengan materi lain mata pelajaran lain sehingga pembelajaran membaca permulaan tetap memiliki orientasi yang jelas. 
Ketiga masalah utama yang terjadi tersebut muncul salah satunya disebabkan oleh kenyataan bahwa model pembelajaran membaca permulaan yang ada selama ini masih belum berkembang khususnya untuk di sekolah dasar kelas awal. Hal ini berbeda dengan munculnya banyak model pembelajaran membaca permulaan yang justru berkembang pada tataran PAUD. Bertemali dengan hal ini, diperlukan optimalisasi model pembelajaran membaca permulaan di kelas awal sekolah dasar yang lebih berorientasi pada pengembangan sikap, keterampilan, dan pengetahuan siswa. Salah satu model yang dapat dioptimalisasi tersebut adalah model Reading Aloud with Compherension (RAC). Hal ini sejalan dengan kenyataan bahwa satu keunggulan model ini jika dibanding model membaca permulaan lain yang hanya berorientasi pada kemampuan membaca nyaring tanpa pemahaman, model ini cocok untuk membina kemampuan membaca permulaan dan sekaligus membangun pemahaman siswa. Melalui model ini, diharapkan pembelajaran membaca permulaan yang dilaksanakan di kelas satu sekolah dasar tetap menantang para siswa untuk belajar bahasa Indonesia.

\section{B. METODE PENELITIAN}

Metode penelitian yang digunakan dalam penelitian ini adalah penelitian mixed methods tipe eksplanatori. Subjek penelitian ini adalah guru dan siswa sekolah dasar di Kecamatan Cileunyi Kabupaten Bandung dan Kecamatan Ujungberung Kota Bandung.

Instrumen yang digunakan untuk mengumpulkan data penelitian ini adalah (1) kuesioner (2) pedoman wawancara semi terstruktur untuk mengumpulkan data respons guru tentang desain (3) tes untuk mengukur kemampuan membaca siswa, (4) penilaian proses berbentuk skoring rubrik untuk mengukur aktivitas siswa, (5) catatan lapangan untuk mengumpulkan data hasil kegiatan observasi, (6) panduan penilaian proses pembelajaran membaca, dan (7) dokumentasi untuk mengumpulkan data proses pelaksanaan penelitian. Berdasarkan jenis instrumen yang digunakan, penelitian ini menghasilkan dua jenis data yakni data kualitatif yang diolah secara kualitatif dan data kuantitatif yang diolah dengan menggunakan metode statistik yaitu uji beda (t) dan uji anova.

\section{HASIL PENELITIAN}

Berdasarkan hasil uji eksperimen yang dilakukan sebanyak tiga kali pembelajaran diketahui bahwa pada ketiga kali eksperimen yang dilakukan kemampuan membaca siswa mengalami peningkatan secara signifikan. Hal ini menunjukkan bahwa penerapan Model Pembelajaran RAC pada saat eksperimen memberikan kontribusi secara signifikan terhadap peningkatan kemampuan membaca siswa. Peningkatan ini terjadi pada setiap tahapan eksperimen. Dengan 
demikian, model yang digunakan mampu digunakan meningkatkan kemampuan membaca siswa.

Berdasarkan hasil pembelajaran di kelas kontrol yang dilaksanakan di tiga kelas kontrol, diketahui bahwa model pembelajaran membaca konvensional secara signifikan berkontribusi pula bagi peningkatan kemampuan siswa dalam membaca pemahaman. Walaupun demikian, jika dibandingkan dengan Model Pembelajaran RAC yang diterapkan di sekolah eksperimen, yang secara signifikan memberikan perbedaan kemampuan membaca pada setiap kali pembelajaran, model pembelajaran yang biasa digunakan ini hanya mampu secara signifikan memberikan perbedaan kemampuan membaca setelah dilaksanakan tiga kali proses pembelajaran.

Guna membuktikan keefektifan tersebut selanjutnya dilakukan pengujian dengan uji t dan hasilnya adalah sebagai berikut.

Tabel 2

Hasil Uji t Kemampuan Membaca antara Kelas Eksperimen dan Kelas Kontrol

\begin{tabular}{|c|c|c|c|c|}
\hline & & & \multicolumn{2}{|c|}{ Kemampuan Membaca Permulaan } \\
\hline & & & $\begin{array}{c}\text { Equal variances } \\
\text { assumed }\end{array}$ & $\begin{array}{c}\text { Equal variances } \\
\text { not assumed }\end{array}$ \\
\hline \multirow{2}{*}{\multicolumn{2}{|c|}{$\begin{array}{l}\text { Levene's Test for } \\
\text { Equality of } \\
\text { Variances }\end{array}$}} & $\mathrm{F}$ & .099 & \\
\hline & & Sig. & .753 & \\
\hline \multirow{7}{*}{$\begin{array}{l}\text { t-test for } \\
\text { Equality of } \\
\text { Means }\end{array}$} & & $\mathrm{t}$ & 6.037 & 6.038 \\
\hline & & df & 183 & 182.980 \\
\hline & & Sig. (2-tailed) & .000 & .000 \\
\hline & & Mean Difference & 11.28799 & 11.28799 \\
\hline & & $\begin{array}{l}\text { Std. Error } \\
\text { Difference }\end{array}$ & 1.86965 & 1.86943 \\
\hline & \multirow{2}{*}{$\begin{array}{l}95 \% \text { Confidence } \\
\text { Interval of the } \\
\text { Difference }\end{array}$} & Lower & 7.59915 & 7.59957 \\
\hline & & Upper & 14.97682 & 14.97640 \\
\hline
\end{tabular}

Berdasarkan data dalam tabel di atas, diketahui bahwa nilai t sebesar 6,04 dengan Sig. (2-tailed) sebesar 0,00 yang lebih kecil dari alfa 0,05. Hal ini berarti bahwa model pembelajaran RAC yang digunakan memiliki tingkat efektivitas yang lebih tinggi bagi peningkatan kemampuan membaca siswa SD dibanding model yang biasa digunakan di sekolah. Hal ini membuktikan Model Pembelajaran RAC efektif meningkatkan kemampuan membaca siswa sekolah dasar. 


\section{PEMBAHASAN}

\section{Model Pembelajaran Reading Aloud with Comprehension (RAC)}

Model Pembelajaran RAC yang digunakan dalam penelitian ini adalah model pembelajaran literasi membaca yang berorientasi pada pengembangan proses dan hasil pembelajaran (Hahn, 2002). Sejalan dengan tujuannya, model ini memiliki fungsi dan peran penting dalam mengembangkan pembelajaran yang baik, yakni pembelajaran membaca yang sesuai konsep membaca yang tepat, mengembangkan kebiasaan memahami bacaan secara cermat dan kreatif, serta pada akhirnya akan berdampak pula pada peningkatan kemampuan membaca siswa.

Proses pembelajaran membaca yang berbasis model ini memerlukan kerja guru secara total. Hal ini berarti harus ada keseriusan guru dalam mengembangkan pembelajaran yang harmonis, bermutu, dan bermartabat. Melalui penerapan Model Pembelajaran RAC, pembelajaran dibangun atas kesadaran peran bersama antara guru dan siswa. Sistem kolegalitas, keterbukaan, dan nuansa pengembangan pengetahuan mulai terbentuk melalui penerapan ini. Kondisi ini lebih jauh mendorong terciptanya iklim belajar yang kondusif karena pembelajaran diawali dengan pembentukan sikap positif, baik pada diri guru maupun pada diri siswanya. Siswa pada akhirnya selalu dibiasakan belajar dengan diawali kesadaran mengapa dan untuk apa mereka belajar.

Model Pembelajaran RAC juga dipandang mampu membangun pembelajaran membaca yang lebih bermutu. Hal ini sejalan dengan kenyataan bahwa model ini menuntut pembelajaran membaca senantiasa dilaksanakan dengan menerapkan sintaks yang relevan dengan kegiatan membaca (Lance, et. al., 2003). Berdasarkan kondisi ini, hal kedua yang dikembangkan pada diri siswa adalah keterampilannya dalam membaca yang bukan hanya keterampilan yang bersifat fisik melainkan juga keterampilan yang bersifat mental. Dalam hal ini siswa dibiasakan mengkaji sebuah wacana melalui cara-cara ilmiah berbasis teks sehingga keterpahaman dan kebertahanan pemahaman isi wacana menjadi lebih baik. Melalui pembelajaran yang demikian, siswa akan dibiasakan memperoleh pengetahuan berbasis keterampilan sehingga pemerolehan pengetahuan tersebut lebih bersifat konstruktif dan kreatif (Swason, et al., 2011).

Selain mampu membangun pembelajaran harmonis dan bermutu, Model Pembelajaran RAC juga telah mampu membangun pembelajaran yang bermartabat. Pembelajaran yang bermartabat merupakan pembelajaran yang dilakukan atas dasar usaha aktif yang dilandasi nilai-nilai karakter. Melalui Model Pembelajaran RAC, pengetahuan kognitif yang dibentuk tidak semata-mata dilandaskan pada kemampuan intelektual siswa melainkan dilandaskan pada asas kerja sama, kepedulian, kejujuran, kegigihan, dan nilai-nilai karakter lain. 
Berdasarkan kondisi ini, intelektualitas yang dikembangkan pada diri siswa juga disertai dengan pengembangan karakter dalam dirinya. Berdasarkan kenyataan ini, Model Pembelajaran RAC dinilai mampu membentuk pribadi unggul yang memiliki kecerdasan yang baik dan karakter yang mulia.

Berdasarkan hasil penelitian, Model Pembelajaran RAC yang digunakan memiliki beberapa keunggulan dibandingkan dengan model lain yang biasa digunakan di sekolah. Minimal ada lima keunggulan model pembelajaran RAC. Keunggulan pertama adalah bahwa Model Pembelajaran RAC didesain sejalan dengan metode membaca pemahaman digunakan. Atas dasar penggunaan model yang tepat ini pembelajaran berlangsung lebih kondusif dan secara langsung mampu meningkatkan kompetensi siswa. Hal ini sejalan dengan pendapat Joyce, dkk. (2009: 23) yang menyatakan bahwa penggunaan model pembelajaran diyakini mampu meningkatkan ketercapaian tujuan pembelajaran.

Keunggulan yang kedua adalah bahwa Model Pembelajaran RAC yang digunakan dikhususkan pada proses membaca sehingga model ini disusun berbasis aktivitas nyata para siswa selama membaca. Sejalan dengan jelasnya tahapan aktivitas ini, guru dapat lebih memantau tingkat kesulitan siswa selama pembelajaran karena Model Pembelajaran RAC tersebut benar-benar mampu memiliki fungsi formatif selama proses pembelajaran. Hal ini sejalan dengan pendapat Popham (2011: 5) yang menyatakan bahwa formatif merupakan penilaian yang dilakukan selama proses pembelajaran berdasarkan hasil aktivitas nyata siswa selama pembelajaran sehingga penilaian ini akan mampu memberikan umpan balik secara nyata bagi kemajuan belajar yang dicapai para siswa.

Keunggulan yang ketiga adalah bahwa Model Pembelajaran RAC yang digunakan telah mampu membiasakan siswa untuk memiliki karakter selama proses pembelajaran. Melalui aktivitas nyata yang dilakukan sejalan model pembelajaran, siswa secara tidak sadar telah dibiasakan untuk menumbuhkan nilai karakter inti dan universal meliputi (1) jujur, (2) cerdas, (3) peduli, dan (4) tangguh. Keempat nilai karakter ini selanjutnya dikembangkan secara spesifik sesuai dengan aktivitas otentik yang dilakukan siswa selama pembelajaran.

Keunggulan keempat adalah bahwa Model Pembelajaran RAC yang digunakan tidak hanya menyajikan aktivitas umum dalam pembelajaran melainkan berisi sejumlah aktivitas yang berorientasi pada pada pembentukan kebiasaan membaca yang baik. Kebiasaan membaca dalam penelitian ini bukanlah kebiasaan membaca yang bersifat perilaku fisik/ visual membaca melainkan lebih bersifat olah kognitif. Kebiasaan membaca yang dimaksud adalah kebiasaan siswa dalam membangun pengetahuan berdasarkan bahan bacaan yang dibacanya, meliputi kebiasaan menangkap ide secara cermat, mengolah ide secara tepat dan kooperatif, serta kebiasaan mengekspresikan ide yang diperoleh secara kreatif dan 
bertanggung jawab. Berdasarkan kenyataan ini, Model Pembelajaran RAC yang digunakan melahirkan pemikiran baru bahwa kebiasaan membaca bukan hanya bersifat fisik/ visual, melainkan yang lebih penting bersifat mental/ kognisi.

Keunggulan kelima adalah bahwa Model Pembelajaran RAC yang digunakan dilengkapi dengan lembar kerja proses yang menggiring siswa bekerja berdasarkan tuntutan model pembelajaran. Berdasarkan kondisi ini, walaupun guru tidak menguasai model pembelajaran membaca dengan baik, guru dan siswa dengan sendirinya akan melaksanakan dan mengikuti pembelajaran berbasis aktivitas pembelajaran otentik selaras dengan model pembelajaran. Penggunaan lembar kerja proses berdampak pada peningkatan kemampuan siswa secara langsung dan bertahap sejalan dengan prinsip pembelajaran bertahap sebagai yang dikemukakan oleh Axfor, Harders, \& Wise (2009: 3) yang menyatakan bahwa melalui pembelajaran bertahap ini siswa akan beroleh seperangkat keterampilan, strategi, dan pengetahuan yang kompleks.

\section{Kontribusi Model Pembelajaran RAC terhadap Pengembangan Kemampuan Membaca}

Model Pembelajaran RAC yang digunakan dalam penelitian ini juga terbukti secara signifikan memberikan kontribusi yang positif terhadap peningkatan kemampuan membaca siswa sekolah dasar. Peningkatan ini terjadi pada seluruh sekolah sampel, yang berarti bahwa model Model Pembelajaran RAC tidak hanya berfungsi bagi siswa yang berkemampuan tinggi tetapi juga bagi siswa yang berkemampuan rendah. Model Pembelajaran RAC yang digunakan dalam penelitian ini dikemas melalui aktivitas berpikir. Sejalan kenyataan tersebut, siswa dibiasakan mengolah wacana dengan berbagai strategi yang tepat. Sejalan dengan strategi yang digunakannya tersebut siswa lebih bisa menggali isi wacana secara mendalam dan kontekstual sehingga pemahamannya pun menjadi meningkat. Keberhasilan peningkatan kemampuan membaca melalui aktivitas ini sejalan dengan penelitian yang pernah dilakukan Greenleaf, dkk. (2010: 3) yang mengembangkan model pembelajaran reading apprenticeship yang juga mengandalkan aktivitas sebagai stimulus bagi pengembangan kemampuan siswa dalam membaca pemahaman.

Pembelajaran membaca dengan mengoptimalkan aktivitas otentik pada dasar adalah menciptakan model pembelajaran literasi membaca berbasis aktivitas siswa. Kondisi ini sama halnya dengan penelitian Greenleaf, dkk. (2010: 3). Oleh sebab itu, wajarlah jika Model Pembelajaran RAC terbukti mampu mengembangkan kemampuan membaca pemahaman siswa. Ahli lain yang mengembangkan pembelajaran membaca berbasis aktivitas yang relevan dengan Model Pembelajaran RAC adalah Bryant, dkk. (2009:1 ). Bryant, dkk. (2009: 1) 
berdasarkan hasil penelitiannya menyimpulkan bahwa interaksi secara langsung yang dilakukan siswa terhadap teks bacaan pada tahap prabaca, membaca, dan pascabaca akan membangun pengetahuan siswa atas materi yang dipelajarinya.

Dalam kaitannya dengan penyusunan lembar kerja proses sebagai bentuk penilaian otentik selama proses pembelajaran membaca, Model Pembelajaran RAC yang digunakan dalam penelitian ini sejalan dengan temuan penelitian yang dilakukan oleh Alonzo, dkk. (2009: 1). Alonzo, dkk. (2009: 1) menyimpulkan bahwa keberagaman penilaian akan membangun pemahaman lebih tinggi pada diri para siswa.

Sejalan uraian di atas dapat dikatakan bahwa Model Pembelajaran RAC yang digunakan dalam penelitian telah terbukti pula meningkatkan mutu proses pembelajaran membaca di sekolah. Hal ini disebabkan oleh kenyataan bahwa Model Pembelajaran RAC pada dasarnya adalah pengembangan pembelajaran yang kreatif, inovatif, dan produktif. Melalui penerapan model ini, diakui guru bahwa pembelajaran membaca menjadi lebih menarik dan kreatif sehingga siswa tertantang untuk mampu membaca secara lebih baik pada seluruh ragam wacana kelas awal sekolah dasar. Hal ini sejalan dengan temuan Shanahan, T and Lonigan, C. J. (2010) yang menyatakan keberhasilan pembelajaran membaca pada kelas awal tergantung pada penciptaan pembelajaran kreatif dan menyenangkan.

Berdasarkan analisis holistik diketahui juga bahwa model ini memberikan motivasi bagi siswa untuk senantiasa membaca. hal ini menyebabkan intensitas membaca siswa menjadi tinggi. Ragam bacaan yang digunakan juga mampu memotivasi siswa untuk senantiasa membaca. Hal ini sejalan dengan hasil penelitian Mol et al. (2009) yang menyimpulkan bahan ajar interaktif mampu mengembangkan kemampuan membaca siswa. Strategi pembelajaran membaca di sisi lain juga menjadi faktor keberhasilan pembelajaran membaca yang dilakukan. Hal ini sejalan dengan temuan Walton, P. D., \& Walton, L.M. (2002) yang menyatakan strategi membaca yang tepat dan hierarki mampu membangun kemampuan siswa membaca beragam wacana.

\section{E. KESIMPULAN}

Model Pembelajaran RAC yang digunakan melalui penelitian ini adalah model pembelajaran literasi membaca yang berorientasi pada pengembangan proses dan hasil pembelajaran. Berdasarkan hasil penelitian diketahui bahwa Model Pembelajaran RAC yang digunakan memiliki beberapa keunggulan dibandingkan dengan model lain yang biasa digunakan di sekolah. Perbedaan ini menunjukkan bahwa Model Pembelajaran RAC yang dikembangkan memiliki urgensi penting bagi peningkatan mutu proses dan hasil pembelajaran literasi membaca. 
Berdasarkan hasil penelitian diketahui bahwa Model Pembelajaran RAC terbukti secara signifikan memiliki kontribusi bagi pengembangan kebiasaan dan peningkatan kemampuan membaca siswa. Peningkatan ini terjadi pada seluruh sekolah sampel, yang berarti bahwa Model Pembelajaran RAC tidak hanya berfungsi bagi siswa yang berkemampuan tinggi tetapi juga bagi siswa yang berkemampuan rendah. Menilik kenyataan ini, Model Pembelajaran RAC sangat diperlukan guna meningkatkan kebiasaan dan kemampuan siswa dalam membaca pemahaman dalam beragam jenis teks.

\section{DAFTAR PUSTAKA}

Alonzo, dkk. (2009) "They Read, but How Well Do They Understand?: An Empirical Look at the Nuances of Measuring Reading Comprehension." Assessment for Effective Intervention. 35 (1). pp. 34-44.

Axfor, Harders, \& Wise (2009) Scaffolding Literacy. Australia: ACER Press.

Bryant, D.P., dkk. (2009). "Instructional Strategies for Content-Area Reading Instruction". Intervention in School and Clinic. 34 (5). 293-302.

Greenleaf, C.L. dkk. (2010) "Integrating Literacy and Science in Biology: Teaching and Learning Impacts of Reading Apprenticeship Professional Development". American Educational Research Journal. 44 (1). 647-717.

Hahn, M.L. (2002). Reconsidering Read-Aloud. Portland, Maine: Stenhouse Publishers.

Hamra, A dan Syatriana, E. (2012). "A Model of Reading Teaching for University EFL Students: Need Analysis and Model Design. English Language Teaching. 5 (10). 1-11.

Joyce, B. dkk. (2001) Models of Teaching. New York: Allyn and Bacon.

Shanahan, T and Lonigan, C. J. (2010), et. al. (2003). "Addressing Literacy: Effective Methods for Reading Instruction" Communication Disorders Quarterly. 25 (1). 5-11.

Mol et al. (2009). Interactive Book Reading in Early Education: A Tool to Stimulate Print Knowledge as Well as Oral Language. Review of Educational Research. 79 (2). 979 - 1007.

Popham, W.J. (2011) Transformative Assessment in Action. Alexandria: ASCD.

Sánchez, J.M. (2013). "La Enseñanza De La Lectura En Ámbito Escolar Dentro Del Currículo Español” Didáctica y Educación. 4 (1). 1-13 .

Shanahan, T and Lonigan, C. J. (2010). "The National Early Literacy Panel : A Summary of the Process and the Report" Educational Researcher. 39 (4). 279-285.

Swason, et al. (2011). "A Synthesis of Read-Aloud Interventions on Early Reading Outcomes Among Preschool Through Third Graders at Risk for Reading Difficulties”. Journal of Learning Disabilities. 44 (3). 258 - 275.

Walton, P. D., \& Walton, L.M. (2002). "Beginning Reading by Teaching in Rime Analogy: Effects on Phonological Skills, Letter-Sound Knowledge, Working Memory, and Word-Reading Strategies. Scientific Studies of Reading. 6(1). 79-115. 